\title{
Effects of early and late season defoliation on photosynthesis, growth and yield of mustard (Brassica juncea L.)
}

\author{
N.A. Khan* and P.M. Lone \\ Department of Botany, Aligarh Muslim University, Aligarh-202002, India. *Corresponding author: naf9@lycos.com \\ Received: 21/10/2004, Accepted: 04/01/2005
}

\begin{abstract}
Mustard (Brassica juncea L.) is characterized by a large number of leaves in the lower layers. These leaves are poorly illuminated, remain below the light compensation point and abscise at maturity. The effects of removing $50 \%$ of all leaves taken from the lower half of the plant at 40 (pre-flowering) or 60 (post-flowering) days after sowing (DAS) were studied on photosynthesis and growth at $80 \mathrm{DAS}$ and on yield at harvest. A comparison of stomatal and mesophyll effects on photosynthesis upon removal of such leaves was also made. Defoliation at 40 DAS resulted in a higher rate of photosynthesis $\left(\mathrm{P}_{\mathrm{N}}\right)$, growth and yield compared to defoliation at $60 \mathrm{DAS}$ or the no defoliation control. The non-significant variation in stomatal limitation $\left(\mathrm{I}_{\mathrm{S}}\right.$ ), increased activity of carbonic anhydrase $(\mathrm{CA})$ and constant $\mathrm{C}_{\mathrm{i}} / \mathrm{C}_{\mathrm{a}}$ ratio in defoliated plants suggest that the main effect on $\mathrm{P}_{\mathrm{N}}$ was through enhanced mesophyll rather than stomatal effects. Defoliation at 40 DAS caused the greatest emergence of new leaves with rapid growth, which contributed to maximum leaf area as well as leaf and plant dry masses. The favourable effects of defoliation at 40 DAS on photosynthesis and growth were reflected by seed yield and attributing parameters.
\end{abstract}

Key words: carbonic anhydrase, dry mass, stomatal limitation.

Efeito do desfolhamento precoce e tardio na fotossíntese, crescimento e produção de mostarda (Brassica juncea $\mathbf{L}$.): Mostarda (Brassica juncea L.) tem como característica grande número de folhas nas camadas inferiores, as quais são pouco iluminadas, permanecendo abaixo do ponto de compensação, caindo na maturidade. Os efeitos da remoção de $50 \%$ de todas as folhas da metade inferior de plantas aos 40 (pré-florescimento) ou 60 (pós-florescimento) dias após a semeadura (DAS) foi estudado sobre a fotossíntese e crescimento aos 80 DAS e sobre a produção. Efetuou-se, também, uma comparação dos efeitos estomáticos e do mesófilo sobre a fotossíntese na remoção das folhas. Desfolha aos 40 DAS resultou em maior taxa fotossintética $\left(\mathrm{P}_{\mathrm{N}}\right)$, crescimento e produção, comparada à desfolha aos 60 DAS ou ao controle não desfolhado. A não significativa variação na limitação estomática $\left(\mathrm{I}_{\mathrm{S}}\right)$, aumento da atividade da anidrase carbônica $(\mathrm{CA})$ e constante razão $\mathrm{C}_{\mathrm{i}} / \mathrm{C}_{\mathrm{a}} \mathrm{em}$ plantas desfolhadas sugerem que o principal efeito sobre $\mathrm{P}_{\mathrm{N}}$ ocorreu mediante um aumento do mesofilo ao invés de um efeito estomático. Desfolhamento aos 40 DAS causou a maior emergência de folhas, com rápido crescimento, que contribuiu para uma máxima área foliar, assim como massas secas de folhas e da planta. Os efeitos favoráveis do desfolhamento aos 40 DAS sobre a fotossíntese e o crescimento foram refletidos na produção de sementes e parâmetros de atribuição.

Palavras-chave: anidrase carbônica, limitação estomática, massa seca.

\section{INTRODUCTION}

Mustard (Brassica juncea L.) is an important crop in the tropical regions of the world, characterized by a large number of oblong-shaped leaves in the lower layers of the plant axis (Weiss, 1983). Such leaves contribute to the development of supra-optimal leaf area indices with accompanying self shading and shading by other leaves within the plant axis
(Anten et al., 1995). These leaves have reduced effective solar irradiation and photosynthetic rates $\left(\mathrm{P}_{\mathrm{N}}\right)$. Moreover, they are shed as the crop matures. It was postulated that removal of such shaded leaves may affect growth of new leaves, their photosynthetic capacity and yield of the crop.

Leaf compensatory growth with modified photosynthetic capacity has already been reported (Ericsson et al., 1980; 
Foggo, 1996; Bruening and Egli, 1999; Collin et al., 2000). We have previously shown that removal of such shaded leaves modulates assimilate balance and growth in mustard (Khan and Ahsan, 2000; Khan, 2002; 2003; Khan et al., 2002). The goal of this investigation was to compare the effects of the stage of defoliation, that is, at 40 (pre-flowering) or 60 (postflowering) days after sowing (DAS), on $\mathrm{P}_{\mathrm{N}}$, mesophyll and stomatal response as well as changes in growth and yield.

\section{MATERIAL AND METHODS}

Mustard (Brassica juncea L. cv. Alankar) seeds were sown in $10 \mathrm{~m}^{2}$ plots at the Experimental Field of Aligarh Muslim University, Aligarh, India. A uniform basal application of nitrogen $(\mathrm{N})$, phosphorus $(\mathrm{P})$ and potassium (K) with $18 \mathrm{~g} \mathrm{~N}, 3 \mathrm{~g} \mathrm{P}$ and $3 \mathrm{~g} . \mathrm{K} \mathrm{m}^{-2}$, respectively, was applied at sowing such that the nutrients were non-limiting. At seedling establishment, a uniform population of 12 plants.m2 was maintained.

Defoliation treatments were arranged in a randomized block design. The number of leaves of plants at 40 and 60 DAS was 12 and 32, respectively. At 40 or 60 DAS, $50 \%$ of the total leaf number was removed from the lower half of the plants, i.e., from the lower six nodes. For the control set, all the leaves were left intact. Each treatment was replicated three times.

Photosynthetic parameters and growth were determined at 80 DAS (pod-fill) and yield at harvest (120 DAS). The measurements at 40 (pre-flowering) and 60 (post-flowering) DAS were also made prior to defoliation to serve as control at these stages of plant growth. These stages of the plant cycle have been described elsewhere (Khan and Samiullah, 2003). Photosynthetic parameters, $P_{N}$ and $g_{S}$ were measured in the uppermost three fully-expanded leaves with a portable photosynthesis system (Licor 6200 Nebraska) at light saturating intensity between 11:00-12:00 h. The atmospheric conditions during the experiment were: PAR, 1,060 \pm 35 $\mu$ mol.m ${ }^{-2} . \mathrm{s}^{-1}, \mathrm{C}_{\mathrm{i}}, 280 \pm 10 \mu \mathrm{mol} . \mathrm{mol}^{-1}$; atmospheric $\mathrm{CO}_{2}$, $360 \pm 5 \mu \mathrm{mol}^{\mathrm{mol}} \mathrm{m}^{-1}$; relative humidity, $65 \pm 6 \%$; atmospheric temperature, $22 \pm 2{ }^{\circ} \mathrm{C}$. Stomatal limitation was calculated as described by Farquhar and Sharkey (1982) using $A / C_{i}$ values.

Carbonic anhydrase (CA) activity was determined by the method of Dwivedi and Randhava (1974). The same leaves used for photosynthesis measurements were selected for the CA activity determinations. Leaves were cut into small pieces in $10 \mathrm{~mL}$ of $0.2 \mathrm{~mol} . \mathrm{L}^{-1}$ cysteine at $4^{\circ} \mathrm{C}$. Excess solution was removed and the leaf pieces transferred to a tube containing
$4 \mathrm{~mL}$ phosphate buffer ( $\mathrm{pH}$ 6.8). Then $4 \mathrm{~mL}$ of 0.2 mol.L-1 sodium bicarbonate in 0.002 mol.L $\mathrm{L}^{-1}$ sodium hydroxide and $0.2 \mathrm{~mL}$ of $0.002 \%$ bromothymol blue were added to the tube. After shaking, the tubes were kept at $4^{\circ} \mathrm{C}$ for $20 \mathrm{~min} . \mathrm{CO}_{2}$ liberated during the catalytic action of the enzyme on sodium bicarbonate was estimated by titrating the reaction mixture against $0.05 \mathrm{~N}$ hydrochloric acid.

For growth parameters, leaf number was recorded and their area measured by a leaf area meter (LA 211, Systronics, India). Leaf and plant dry masses of control and defoliated plants were determined after drying in an oven to constant weight. Plants in a one square meter area were harvested, the number of pods recorded, and seeds weighed to calculate 1,000 seed weight and seed yield.

Data were statistically analysed using an Analysis of Variance (ANOVA) with a significance level of $p<0.05$. LSD was calculated and used to identify significant differences. An index of relationships for leaf area, photosynthetic rate, plant dry mass and seed yield was calculated (figure 1). The index number for any treatment was expressed as a percentage relative to the maximum value obtained in a treatment.

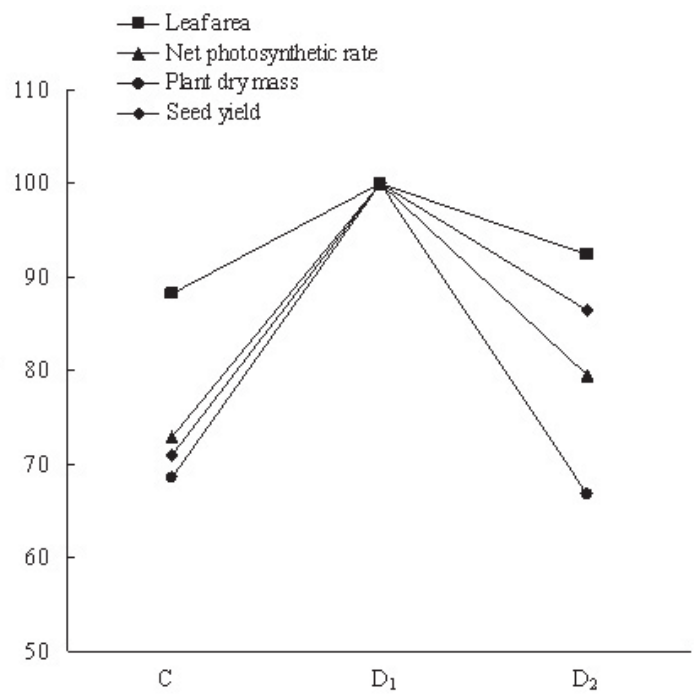

Figure 1. Index of relationships among leaf area, photosynthetic rate, plant dry mass and seed yield of mustard (Brassica juncea L.) following no defoliation $(\mathrm{C})$, defoliation at $40 \mathrm{DAS}\left(\mathrm{D}_{1}\right.$; pre-flowering) or $60 \mathrm{DAS}\left(\mathrm{D}_{2}\right.$; post-flowering). Values obtained by dividing the value in a treatment by the maximum value obtained in any treatment and expressed as percentage.

\section{RESULTS}

Effects of defoliation on photosynthesis: The defoliation treatments increased photosynthetic parameters over the no defoliation control (table 1). Defoliation at 40 DAS increased $\mathrm{P}_{\mathrm{N}}$ and $\mathrm{g}_{\mathrm{S}}$ maximally, whereas defoliation at 60 DAS proved 
less effective in enhancing photosynthetic parameters. The increase in $\mathrm{P}_{\mathrm{N}}$ and $\mathrm{g}_{\mathrm{S}}$ due to defoliation at 40 DAS were 17.8 and $2.4 \%$, respectively, compared to the no defoliation control. The increase in these parameters due to defoliation at 60 DAS was 5.2 and $0.9 \%$, respectively, compared to the control. Stomatal limitation to photosynthesis did not differ significantly. Activity of CA increased with defoliation treatments and the maximum increase was noted with defoliation at 40 DAS, where it was $14.0 \%$ over the control.

Effects of defoliation on growth and yield: Growth and yield were significantly increased by the defoliation treatment (tables 2 and 3). Maximum leaf number, leaf area, leaf and plant dry masses were obtained with defoliation at 40 DAS (table 2). The defoliation treatment at 60 DAS also increased growth of plants in comparison with the no defoliation control, but the increase was lower compared to defoliation at 40 DAS. The per cent increase in leaf number, leaf area, leaf dry mass and plant dry mass due to defoliation at 40 DAS was respectively $13.9,11.9,23.7$ and $16.8 \%$ in comparison with the no defoliation control.

Among yield parameters, pod number, 1000 seed weight and seed yield were enhanced by $10.3,15.2$ and $16.1 \%$, respectively, with defoliation at 40 DAS, whereas the increases in these parameters were respectively 4.8, 6.5 and $7.2 \%$ with defoliation at $60 \mathrm{DAS}$, in comparison with the control (table 3).

\section{DISCUSSION}

The earlier stage of defoliation, 40 DAS, increased photosynthetic parameters maximally (table 1). Partial defoliation is known to have rejuvenating effects on the remaining leaves restoring their photosynthetic capacity (Wareing et al., 1968; Hodgkinson, 1974) since leaf removal reduces at early stages the competition between organs and consequentely the plant can make use of available light, water and nutrients more efficiently. Moreover, the new leaves that emerged following defoliation had a higher photosynthetic capacity than those that emerged at a later stage of plant growth following defoliation at 60 DAS. It has been suggested that crop photosynthesis depends on the distribution of photosynthetically active radiation (PAR) among layers and on the amount absorbed by the canopy (Nobel et al., 1993). It has been shown that leaves of partially defoliated plants had higher assimilatory capacity because they were able to harvest more PAR (Alderfer and Eagles, 1976; Carmi and Koller, 1979;

Table 1. Effect of defoliation of $50 \%$ of the leaves from lower layers of mustard (Brassica juncea) at 40 (pre-flowering) or 60 (post-flowering) days after sowing $(\mathrm{DAS})$ on net photosynthetic rate $\left(\mathrm{P}_{\mathrm{N}}\right)$, stomatal conductance $\left(\mathrm{g}_{\mathrm{S}}\right)$, stomatal limitation $\left(\mathrm{I}_{\mathrm{S}}\right)$ and carbonic anhydrase $(\mathrm{CA})$ activity at 80 DAS.

\begin{tabular}{lcccc}
\hline Treatments & $\begin{array}{c}\mathrm{P}_{\mathrm{N}} \\
\left(\mu \mathrm{mol} . \mathrm{m}^{-2} \cdot \mathrm{s}^{-1}\right)\end{array}$ & $\begin{array}{c}\mathrm{g}_{\mathrm{S}} \\
\left(\mathrm{mmol} . \mathrm{m}^{-2} \cdot \mathrm{s}^{-1}\right)\end{array}$ & $\begin{array}{c}\mathrm{I}_{\mathrm{S}} \\
(\%)\end{array}$ & $\begin{array}{c}\mathrm{CA} \\
\left(\mathrm{mmol}^{-2} \cdot \mathrm{s}^{-1}\right)\end{array}$ \\
\hline Control & 24.6 & 406.0 & 20.0 & 21.4 \\
Defoliation at 40 DAS & 28.8 & 416.0 & 20.6 & 24.4 \\
Defoliation at 60 DAS & 25.9 & 410.0 & 20.4 & 22.9 \\
LSD $(P<0.05)$ & 0.87 & 3.46 & $\mathrm{NS}$ & 1.10 \\
No defoliation control at 40 DAS & 16.3 & 390.0 & 20.3 & 17.2 \\
No defoliation control at 60 DAS & 18.4 & 402.0 & 20.8 & 20.1 \\
\hline
\end{tabular}

Table 2. Effect of defoliation of $50 \%$ of the leaves from lower layers of mustard (Brassica juncea) at 40 (pre-flowering) or 60 (post-flowering) days after sowing (DAS) on leaf number per plant, leaf area per plant, leaf dry mass per plant and plant dry mass at 80 DAS.

\begin{tabular}{lcccc}
\hline Treatments & Leaf number per plant & $\begin{array}{c}\text { Leaf area per plant } \\
\left(\mathrm{cm}^{2}\right)\end{array}$ & $\begin{array}{c}\text { Leaf dry mass } \\
\left(\text { g.plant }{ }^{-1}\right)\end{array}$ & $\begin{array}{c}\text { Plant dry mass } \\
(\mathrm{g} . \text { plant }\end{array}$ \\
\hline Control & 43.0 & 1385.0 & 9.7 & 31.4 \\
Defoliation at 40 DAS & 49.0 & 1551.0 & 12.0 & 36.7 \\
Defoliation at 60 DAS & 46.0 & 1478.0 & 10.5 & 33.2 \\
LSD $(P<0.05)$ & 2.31 & 72.27 & 0.57 & 0.77 \\
No defoliation control at 40 DAS & 12.0 & 640.0 & 3.61 & 6.4 \\
No defoliation control at 60 DAS & 32.0 & 850.0 & 7.63 & 17.2 \\
\hline
\end{tabular}


Table 3. Effect of defoliation of $50 \%$ of the leaves from lower layers of mustard (Brassica juncea) at 40 (pre-flowering) or 60 (post-flowering) days after sowing (DAS) on pod number per plant, 1000 seed weight and seed yield.

\begin{tabular}{lccc}
\hline Treatments & $\begin{array}{c}\text { Pod number } \\
\text { per plant }\end{array}$ & $\begin{array}{c}1000 \text { seed } \\
\text { weight }(\mathrm{g})\end{array}$ & $\begin{array}{c}\text { Seed } \\
\text { yield } \\
\left(\mathrm{g} . \mathrm{m}^{-2}\right)\end{array}$ \\
\hline Control & 165 & 4.6 & 136.0 \\
Defoliation at 40 DAS & 182 & 5.3 & 158.6 \\
Defoliation at 60 DAS & 173 & 4.9 & 145.8 \\
LSD $(P<0.05)$ & 6.27 & 0.10 & 7.82 \\
\hline
\end{tabular}

Cammerer and Farquhar, 1984). Defoliation significantly increased light interception in the crop canopy and lightsaturated photosynthesis per unit leaf area was found to be increased (Gold and Caldwell, 1990; Kruger et al., 1998; Emam and Seghatoleslami, 1999; Anten and Ackerly, 2001). In the present study, the PAR at the top of the plant was 1,060 $\mu \mathrm{mol} . \mathrm{m}^{-2} \cdot \mathrm{s}^{-1}$, in the middle $500 \mu \mathrm{mol} \cdot \mathrm{m}^{-2} \cdot \mathrm{s}^{-1}$ and in the lower layers below $500 \mu \mathrm{mol} \cdot \mathrm{m}^{-2} \cdot \mathrm{s}^{-1}$. The higher increase in $\mathrm{P}_{\mathrm{N}}$ in plants defoliated at 40 DAS was due to mesophyll rather than stomatal effects. Enhanced CA activity and a constant $\mathrm{C}_{\mathrm{i}} / \mathrm{C}_{\mathrm{a}}$ ratio suggest that the increase in $\mathrm{P}_{\mathrm{N}}$ was due to mesophyll effects. $\mathrm{CA}$ accelerates the reaction of $\mathrm{HCO}_{3}{ }^{-}$dehydration and increases the $\mathrm{CO}_{2}$ concentration at the site of carboxylation, thereby contributing to a more efficient ribulose-1,5-bisphosphate carboxylase (Rubisco) activity (Sultemeyer et al., 1993; Khan et al., 2004). Net photosynthetic rate is known to be related to the activity of CA (Khan, 1994; XinBin et al. 2001). Earlier, Khan (2002) noted increased activities of CA and Rubisco following defoliation in mustard. Wareing et al. (1968) found increased photosynthetic rates in the remaining leaves at saturating light intensities after partial defoliation, attributed to increased activities of carboxylating enzymes. Increased stomatal conductance has also been attributed to the increase in photosynthetic rate (Syvertsen, 1994; Belesky and Hill, 1997; Doescher et al., 1997). However, a comparison of the stages of defoliation and the contribution of mesophyll and stomatal effects on $\mathrm{P}_{\mathrm{N}}$ has not been done previously. Stomatal limitation to photosynthesis remained unaltered and an increase in $\mathrm{g}_{\mathrm{S}}$ was to maintain intercellular $\mathrm{CO}_{2}$ concentration.

Growth and yield were enhanced by the defoliation treatment. The increase in these characteristics was maximal with defoliation at 40 DAS. Increased leaf number and leaf area due to defoliation at 40 DAS led to higher $\mathrm{CO}_{2}$ assimilation per plant and thus increased leaf and plant dry masses. The leaf number was increased by 37 and leaf area by $911 \mathrm{~cm}^{2}$ in plants defoliated at 40 DAS relative to the control values at $40 \mathrm{DAS}$. This led to an increase in leaf dry mass per plant of $8.3 \mathrm{~g}$ and in plant dry mass per plant of $30.3 \mathrm{~g}$. However, defoliation at 60 DAS increased leaf number by 14 , leaf area by $701 \mathrm{~cm}^{2}$, leaf dry mass per plant by $2.9 \mathrm{~g}$ and plant dry mass per plant by $16 \mathrm{~g}$ compared to control values at 60 DAS (table 2). Becker et al. (1997) found an increase in leaf production and growth rate when defoliation was carried out at the vegetative stage. Marriot and Haystead (1980) have reported that defoliation up to $45-50 \%$ of leaf number increased rates of leaf emergence and the development of young leaves. The defoliated plants needed higher amount of assimilates for regrowth, which was balanced by the increased assimilatory capacity of the plants evident from increased $\mathrm{P}_{\mathrm{N}}$ in plants defoliated at 40 DAS. An increase in unit leaf rates with defoliation has been shown to compensate for the losses in growth (Anten et al., 2003). It may be emphasized that new top growth is initiated and developed largely at the expense of previously accumulated organic reserves (Graber et al., 1927). Chapin et al. (1990) pointed out that plants must store more reserves than would be required to replace lost canopy tissue because they are also needed to supply respiratory demands of the remaining plant. McPherson and Williams (1998) reported regrowth and recovery after the loss of aboveground tissue were related to the quantity of total nonstructural carbohydrate in belowground organs, and fructan carbohydrate might be used as substrate for growth (Morvan-Bertrand et al., 1999). Saitoh et al. (2001) suggested that the higher growth rate in defoliated plants indicated the excess supply of assimilates from leaves to other organs.

Finally, seed yield in plants defoliated at 40 DAS was higher because of the higher pod number and 1000 seed weight in this treatment (table 3). The smaller increase in seed yield of plants defoliated at 60 DAS may be explained by the defoliation stage coinciding with the start of pod setting where the higher level of photosynthates required was not available. Lower seed weight in plants defoliated at 60 DAS also suggests the inadequate supply of assimilates to the individual seed. Tayo and Morgan (1979) and Pecham and Morgan (1985) showed reduction in yield of Brassica napus due to leaf removal at a later stage of the plant cycle. Ockerby et al. (2001) reported reduced growth and yield in sorghum when defoliation was carried out at anthesis. The index of relationships for leaf area, net photosynthetic rate, plant dry mass and seed yield also showed that a concomitant 
relationship exists among these characteristics and the maximum response was obtained with defoliation at 40 DAS (figure 1).

In conclusion, defoliation at 40 DAS (pre-flowering) has a greater effect on increasing photosynthesis, growth and yield compared to defoliation at 60 DAS (post-flowering). Mesophyll effects were mainly responsible for increasing photosynthesis in response to defoliation.

\section{REFERENCES}

Alderfer RG, Eagles CF (1976) The effect of partial defoliation on the growth and photosynthetic efficiency of bean leaves. Bot. Gaz. 137:351-355.

Anten NPR, Ackerly DD (2001) Canopy-level photosynthetic compensation after defoliation in tropical understorey palm. Funct. Ecol. 15:252-262.

Anten NPR, Martinez-Ramos M, Ackerly DD (2003) Defoliation and growth in an understorey palm: Quantifying the contributions of compensatory responses. Ecology 84 : 2905-2918.

Anten NPR, Schieving F, Medina E, Werger MJA, Schuffelen $\mathrm{P}$ (1995) Optimal leaf area indices in $\mathrm{C}_{3}$ and $\mathrm{C}_{4}$ monoand dicotyledonous species at low and high nitrogen availability. Physiol. Plant. 95:541-550.

Becker GF, Busso CA, Montani T, Orchansky AL, Brevedan RE, Burgos MA, Flemmer AC (1997) Effects of defoliation Stipa tenuis and Piptochaetium napostaense at different phonological stages: demography and growth. J. Arid Environ. 35:251-268.

Belesky DP, Hill NS (1997) Defoliation and leaf age influence on ergot alkaloids in tall fescue. Ann. Bot. 79:259-264.

Bruening WP, Egli DB (1999) Relationship between photosynthesis and seed number of isolated nodes in soybean. Crop Sci. 39:1769-1775.

Cammerer SV, Farquhar GD (1984) Effects of partial defoliation, changes of irradiance during growth, short-term water stress and growth at enhanced $\mathrm{P}\left(\mathrm{CO}_{2}\right)$ on the photosynthetic capacity of leaves of Phaseolus vulgaris L. Planta 160:320-329.

Carmi A, Koller D (1979) Regulating of photosynthetic activity in the primary leaves of bean (Phaseolus vulgaris L.) by materials moving in the water conducting system. Plant Physiol. 64:285-288.

Chapin FS, Schulze E, Mooney HA (1990) The ecology and economics of storage in plants. Annu. Rev. Ecol. Syst. 21: 423-447.

Collin P, Epron D, Alaoui-Sosse B, Badot PM (2000) Growth response of common ash seedlings (Fraxinus excelsior L.) to total and partial defoliation. Ann. Bot. 85:317-323.

Doescher PS, Svejcar TJ, Jaindi RG (1997) Gas exchange of Idaho fescue in response to defoliation and grazing history. J. Range Manag. 50:285-289.

Dwivedi RS, Randhava NS (1974) Evaluation of a rapid test for the hidden hunger in plants. Plant Soil 40:445-451.
Ericsson AS, Larson S, Tenow W (1980) Effects of early and late season defoliation on growth and carbohydrate dynamics in scot pine. Appl. Ecol. 17:747-769.

Emam Y, Seghatoleslami MJ (1999) The effect of defoliation on the pattern of dry matter accumulation and grain yield in hybrid maize (Zea mays L.). Iranian J. Agric. Sci. 30:215-223.

Farquhar GD, Sharkey TD (1982) Stomatal conductance and photosynthesis. Annu. Rev. Plant Physiol. 33:317-345.

Foggo A (1996) Long-and short-term changes in plant growth following simulated herbivory: adaptive responses to damage. Ecol. Entomol. 21:198-202.

Gold WG, Caldwell MM (1990) The effects of the spatial pattern of defoliation on regrowth of a tussock grass. III. Photosynthesis: canopy structure and light interception. Oecologia 82:12-17.

Graber IF, Nelson NJ, Luckel WA, Albert WB (1927) Organic food reserve in relation to the growth of alfafa and other perennial herbaceous plants. Wisconsin Agric. Expt. Station Bull. 80:1-128.

Hodgkinson KC (1974) Influence of partial defoliation on photosynthesis, photorespiration and transpiration by Lucerne leaves of different ages. Aust. J. Plant Physiol. 1: 561-576.

Khan NA (1994) Variation in carbonic anhydrase activity and its relationship with photosynthesis and dry mass of mustard. Photosynthetica 30:317-320.

Khan NA (2002) Activities of carbonic anhydrase and ribulose-1,5-bisphosphate carboxylase, and dry mass accumulation in Brassica juncea following defoliation. Photosynthetica 40:633-634.

Khan NA (2003) Changes in photosynthetic biomass accumulation, auxin and ethylene level following defoliation in Brassica juncea. Food Agric. Environ. 1:125-128.

Khan NA, Ahsan N (2000) Evaluation of yield potential of defoliated mustard cultivars. Tests Agro Chem. Cultivars 21:33-34.

Khan NA, Javid S, Samiullah (2004) Physiological role of carbonic anhydrase in $\mathrm{CO}_{2}$ fixation and carbon partitioning. Physiol Mol. Biol. Plants 10:153-166.

Khan NA, Khan M, Ansari HR, Samiullah (2002) Auxin and defoliation effects on photosynthesis and ethylene evolution in mustard. Sci. Hortic. 96:43-51.

Khan NA, Samiullah (2003) Comparative effect of modes of gibberellic acid application on photosynthetic biomass distribution and productivity of rapeseed-mustard. Physiol. Mol. Biol. Plants 9:141-145.

Kruger EL, Volin JC, Lindroth RL (1998) Influence of atmospheric $\mathrm{CO}_{2}$ enrichment on the responses of sugar maple and trembling aspen to defoliation. New Phytol. 140:85-94.

Marriot CA, Haystead A (1990) The effect of defoliation on the nitrogen economy of white clover: regrowth and the remobilization of plant organic nitrogen. Ann. Bot. 66:465-474.

McPherson K, Williams K (1998) The role of carbohydrate reserves in growth, resilience and persistence of cabbage palm seedlings (Sabal palmetto). Oecologia 117:460-468. 
Morvan-Bertrand A, Pavis N, Boucand J, Prud'homme MP (1999) Partitioning of reserve and new assimilated carbon in roots and leaf tissues of Lolium perenne during regrowth after defoliation: assessment by ${ }^{13} \mathrm{C}$ steady-state labelling and carbohydrate analysis. Plant Cell Environ. 22:1097-1108.

Nobel PS, Forseth IN, Long SP (1993) Canopy structure and light interception. In: Hall DO, Scurlock JMO, Bolhar-Nordenkampf HR, Leegood RC, Long SP (eds), Photosynthesis and Production in a Changing Environment, pp.79-90. Chapman and Hall, London.

Ockerby SE, Midmore DJ, Yule DF (2001) Leaf modification delays panicle initiation and anthesis in grain sorghum. Aust. J. Agric. Res. 52:127-135.

Pecham PA, Morgan DG (1985) Defoliation and its effects on pod and seed development in oil seed rape (Brassica napus L.). J. Exp. Bot. 36:458-468.

Saitoh K, Isobe S, Sequchi Y, Kuroda T (2001) Effects of source and/or sink restriction on the number of flowers, yield and dry matter production in field-grown soybean. Japanese J. Crop Sci. 70:365-372.

Sultemeyer D, Schmidt C, Fock HP (1993) Carbonic anhydrases in higher plants and aquatic microorganisms. Physiol. Plant. 88:179-190.

Syvertsen JP (1994) Partial shoot removal increases net $\mathrm{CO}_{2}$ assimilation and alters water relations of Citrus seedlings. Tree Physiol. 14:497-508.

Tayo TO, Morgan DG (1979) Factors influencing flower and pod development in oil seed rape (Brassica napus L.). J. Agric. Sci. 92:363-373.

Wareing PF, Khalifa MM, Treharne KJ (1968) Rate-limiting processes in photosynthesis at saturating light intensities. Nature 220:453-457.

Weiss EA (1983) Oilseed crops. Longman, New York.

XinBin D, RongXian Z, Wei L, XiaMing X, ShuQing C (2001) Effects of carbonic anhydrase in wheat leaf on photosynthetic function under low $\mathrm{CO}_{2}$ concentration. Sci. Agric. Sinica 34:97-100. 